\title{
A COMPREHENSIVE DEFINITION AND TYPOLOGY OF ANGLICISMS IN PRESENT-DAY SPANISH ${ }^{1}$
}

\author{
ANGLICISMOS EN EL ESPAÑOL ACTUAL: DEFINICIÓN Y TIPOLOGÍA
}

\author{
Eugenia Esperanza Núñez Nogueroles \\ Universidad de Granada \\ eugenia@ugr.es
}

Fecha de Recepción: 11-01-2018

Fecha de Aceptación: 01-10-2018

\section{Abstract}

The aim of the present piece of research is twofold. On the one hand, it attempts to provide a clear and accurate definition of the term Anglicism. On the other hand, it delves deeply into the different loanword classifications that have been expounded so far in order to take them as the basis for elaborating an inclusive, comprehensive and consistent typology of Anglicisms as they are used in present-day Spanish. This taxonomy improves the existing ones in that it covers true as well as false Anglicisms and, moreover, it adds two new categories of pseudo-Anglicisms.

KEY WORDS: Anglicisms; typology; loanword; Spanish language

${ }^{1}$ This piece of research has been funded by a scholarship granted by the Spanish Ministry of Education, Culture and Sport, and has been carried out at the University of Granada. 


\section{RESUMEN}

El presente trabajo de investigación se propone, por un lado, proporcionar una definición clara y precisa del término anglicismo y, por otro, ahondar en las diferentes clasificaciones de préstamos que se han publicado hasta el momento, con el objetivo de tomarlas como base para la elaboración de una tipología sólida, compleja y completa de los anglicismos empleados en el español actual. Esta taxonomía supondrá un avance con respecto a las ya existentes, dado que incluirá tanto los anglicismos auténticos como los falsos y, además, añadirá dos nuevas categorías al ámbito de los pseudo-anglicismos.

PALABRAS ClAVE: anglicismos; tipología; préstamo; lengua española

\section{INTRODUCTION}

A great variation concerning the terminological labels employed in the literature to refer to the different types of borrowing in general and Anglicisms in particular can be observed when approaching the high number of pieces of research devoted to this interesting linguistic phenomenon. Moreover, the way of arranging the various kinds of loanwords varies from author to author. Therefore, this amount of terms and typologies shrouds the study of this area in an enormous complexity.

It turns out to be necessary, thus, to delve into the field of loanwords with the aim of suggesting a clear and accurate definition of the term Anglicism as well as proposing a comprehensive and consistent typology which will cover all the types of English loans that are employed in present-day Spanish.

\section{LITERATURE REVIEW}

In his insightful book Préstamos del español: lengua y sociedad, Gómez Capuz (2004) presents a comprehensive study of loanwords in the Spanish language, providing us with several classifications that have been proposed in various historical periods to create a frame in which this issue could be properly analised. First, he comments upon the distinct features that distinguish the North-American from the European tradition, two schools dedicated to analyse linguistic borrowing from the mid-twentieth century onwards. Second, he makes reference to Leonard Bloomfield (1933), who differentiated between three types of borrowing, namely, cultural, intimate, and dialectal. Afterwards, Gómez Capuz moves on to explain the formalist classifications that appeared in Germany during the first half of the $20^{\text {th }}$ century. Finally, he develops and defends a taxonomy based on the linguistic level which is affected by the borrowing process.

El anglicismo en el español peninsular contemporáneo, published by Pratt in 1980, is considered as a landmark in the field of borrowing from English into Spanish. The author elaborates a complex classification of Anglicisms, which has had a great number of 
followers among the scholars devoted to the study of English loanwords in the mentioned recipient language. This classification was structured in a table format by Medina López (2004 [1996]), an adaptation of which is reproduced in what follows:

TABLE I.

“Según Pratt (1980)”. Adapted from Medina López (1996, p. 25)

\begin{tabular}{|c|c|c|c|c|}
\hline \multicolumn{5}{|c|}{ Anglicismos } \\
\hline \multirow{8}{*}{ Léxicos } & \multirow{5}{*}{ Univerbales } & \multicolumn{3}{|c|}{ Anglicismo patente } \\
\hline & & \multirow{4}{*}{$\begin{array}{l}\text { Anglicismo no } \\
\text { patente }\end{array}$} & \multirow{2}{*}{ Voces tradicionales } & Parónimos \\
\hline & & & & Calcos \\
\hline & & & \multirow{2}{*}{ Voces neológicas } & Absoluto \\
\hline & & & & Derivado \\
\hline & \multirow{3}{*}{ Multiverbales } & \multicolumn{3}{|c|}{ Anglicismos compuestos bisustantivales } \\
\hline & & \multicolumn{3}{|c|}{ Anglicismos bisustantivales univerbales } \\
\hline & & \multicolumn{3}{|c|}{ Anglicismos paranominales } \\
\hline \multirow{2}{*}{ Sintácticos } & \multicolumn{4}{|c|}{ la ampliación de uso de la estructura preexistente } \\
\hline & \multicolumn{4}{|c|}{ la innovación sintáctica } \\
\hline
\end{tabular}

Meanwhile, Medina López (2004 [1996] $)^{2}$ also claims that, in order to establish a typology of Anglicisms, a double perspective should be taken into account: lexical Anglicisms, on the one hand, and syntactic Anglicisms, on the other hand. Following this idea, he presents several classifications portrayed by different authors. In regard to the first group, there are two main criteria to organise a typology: (1) frequency of use - as well as the number of speakers that have employed the lexical item - and (2) linguistic criteria adopted in the analysis. As for the second group, the author posits that "[1] as construcciones sintácticas - con evidentes evocaciones anglosajonas - se registran en varias partes de la oración" (p.73), and he comments upon some of them: passive voice with the verb to be, adverbs, prepositions, plural formation and verbs followed by prepositions.

With a focus only on lexical borrowing, Pulcini et al. (2012) $)^{3}$ depict a typology which draws "on different scholarly views of language contact" (p.6). To visually represent this classification, the authors include the following figure (p.6): ${ }^{4}$

\footnotetext{
2 Medina López, El anglicismo en el español actual.

${ }^{3}$ Pulcini, Furiassi, and Rodríguez González, 'The Lexical Influence of English on European Languages. From Words to Phraseology'.

${ }^{4}$ For the explanations on each type of borrowing, vide Pulcini et al. (2012, pp. 6-10).
} 


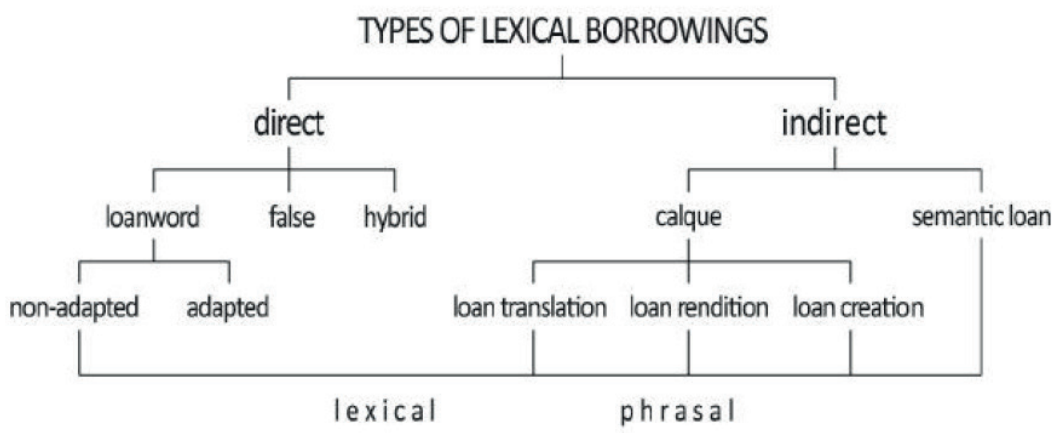

Figure I.

Typology of lexical borrowing by Pulcini et al. (2012, p. 6)

Sustaining a wider perspective, Gómez Capuz $(1992)^{5}$ puts forward the following taxonomy:

a.) Orthographic Anglicisms (transliterations): ${ }^{6}$ they consist of transliterating a proper noun - a place name or an anthroponomy - from a language that does not use the Latin alphabet, according to the English rather than the Spanish orthographic and phonemic rules. ${ }^{7}$ This kind of Anglicism is not included in the lexical level, since the borrowing just implies spelling combinations.

b.) Semantic Anglicisms: the recipient language receives a new sense for an already existing word; therefore, it does not affect the lexical level. In this point the author refers to John Humbley's (1974) classification, which, according to Gómez Capuz, adapts and improves Einar Haugen's (1950) proposal.

— Homólogos (calco semántico) — counterpart (semantic calque)—: it occurs when the word, in the donor as well as in the receiving languages, differs in the signifier but shares at least one seme. This way, it is easy for the source language word to transfer a second seme to the target language word. Anglicisms of this kind are, in a sense, borrowed metaphors.

- Análogos (anglicismo semántico paronímico) —analogues (paronymic semantic Anglicism) - : when there is a formal similarity between a word in the donor language and a word in the recipient language (they go back to a same Latin etymon), and they also have at least one seme in common. ${ }^{8}$

5 Gómez Capuz, 'Anglicismos en las noticias sobre la Guerra del Golfo Pérsico'.

${ }^{6}$ On the contrary, Navarro (2008) does not use the label "anglicismos ortográficos" to refer to transliterations but to elements such as graphic accents, diaeresis, and other diacritic signs, which are omitted in Spanish due to the English influence.

7 For more on this issue, vide de Madariaga (1966) and Lapesa Melgar (1973).

${ }^{8}$ Lodares (1993) clarifies that an English word that shares with a Spanish one a common etymological origin and the same —or similar — spelling, but whose meanings in each of the two languages are different, constitutes 
c.) Lexical Anglicism: it takes place when the receptor language absorbs a whole word (signifier + signified) from another language. This can be performed in three different ways: the item is transmitted as it is in the original language (importación, transferencia o préstamo patente) $;{ }^{9}$ the item is translated by means of the receiving language morphemes (sustitución, reproducción o calco) $;{ }^{10}$ the two previous procedures are combined (híbrido). ${ }^{11}$

d.) Syntactic calque or syntactic Anglicism: syntactic infiltration.

Finally, the author concludes that "la verdadera amenaza para nuestro idioma radica en los tipos de anglicismos que no pasan por el nivel léxico, y que así pasan más desapercibidos al hablante medio: los ortógrafos, los semánticos y los sintácticos” (p.319).

The last type of Anglicism dealt with by Gómez Capuz (1992), i.e. syntactic Anglicisms, is tackled by Navarro (2008). ${ }^{12}$ In this paper, the author concentrates on seven out of the different sub-types of syntactic Anglicisms: (1) determiner article omission, (2) recurrent use of the periphrastic passive, (3) alien use of the gerund form, (4) English adjectivally use, (5) noun order inversion, (6) use of the mal-prefix with feminine nouns, and (7) use of the adverb no to complement nouns and adjectives. ${ }^{13}$

what traditionally has been called as false friends. When the foreign meaning is introduced in the native language due to the formal similarity, we face an Anglicism.

${ }^{9}$ Import, transference, or overt loanword.

${ }^{10}$ Substitution, reproduction, or calque. It refers to what Gómez Capuz (2005, pp.36-41) names calco estructural or calco léxico (lexical or structural calque): "al reproducir una construcción o compuesto extranjero mediante materiales de la lengua receptora, se acaba creando en esa misma lengua receptora un compuesto no existente como tal antes del proceso del préstamo. En otras palabras, el calco crea una nueva lexía compleja (significante + significado) en la lengua receptora. Además, esto constituye el criterio decisivo para la distinción entre el calco estructural léxico y el calco semántico (...), ya que éste último se limita a modificar el significado de una palabra ya existente en la lengua receptora: aunque ambos procedimientos se basen en una traducción, lo distintivo para el sistema es que rascacielos y gratte-ciel (calcos estructurales del inglés sky-scraper) son nuevas lexías complejas del español y del francés, mientras que halcón y épervier en el sentido de 'político de línea dura' (calcos semánticos del inglés hawk en su acepción figurada del lenguaje político) no constituyen nuevas lexías (significante + significado) sino tan sólo la adición de un nuevo significado a una palabra ya existente en la lengua receptora (...) Por tanto, definiremos el calco estructural o léxico como la sustitución de una palabra polimorfemática o compuesto nominal de la lengua modelo (...) por medio de morfemas o lexías simples ya existentes por sí solos en la lengua receptora, de manera que la unión de estos elementos dé lugar a una expresión polimorfemática o lexía compleja desconocida antes en esta lengua" (pp.38, 39).

${ }^{11}$ Therefore, according to Gómez Capuz (1992), a hybrid is a combination of "import" and "substitution" (i.e. una "categoría mixta de préstamo y calco" — Gómez Capuz, 1998, p.77—). At this point, it would be interesting to go into a digression on the differences expressed by various authors about the concept of "hybrid". As Gómez Capuz (1998, pp.77-78) summarises, the European tradition defines a hybrid as "un neologismo culto compuesto por un elemento griego y otro latino o románico" (restricting the term just to refer to "híbrido[s] grecolatino[s]), whereas the North-American tradition, from a formalist and modern point of view, considers that "dicho concepto se puede aplicar a los hechos de préstamo entre lenguas modernas".

${ }_{12}$ Navarro, 'La anglización del español: Mucho más allá de bypass, piercing, test, airbag, container y spa'.

${ }^{13}$ For more on syntactic Anglicisms, vide Estrany Gendre (1970). 
Syntactic Anglicisms are linked, to a certain extent, to frequency Anglicisms. The latter are studied in-depth in Vázquez-Ayora (1977). ${ }^{14}$ The fourth chapter of his well-known book Introducción a la Traductología. Curso básico de traducción is devoted to this phenomenon, which

es causado por la 'frecuencia' insólita con la que aparece algún 'giro'o 'término' sin que ese giro o término sea necesariamente un anglicismo en sí. Puede no ser giro extranjero, más su repetición en el uso no es castiza, y en ello se distingue de las otras clases de anglicismos que hemos conocido antes. Puede ser (...) 'léxico'o 'estructural', y a veces puede afectar inclusive a períodos enteros, por la forma en que están construidos (estructuras extrañas) (Vázquez-Ayora, 1977, p.103).

Frequency Anglicisms ${ }^{15}$ are in a way related to syntactic ones because a number of examples are classified as belonging to both categories. This point is covered in Rodríguez Medina (2002), ${ }^{16}$ who sustains that "[s]yntactic Anglicisms of frequency occur in Spanish when the use of certain syntactic structures is increased as a result of the influence of the English language, where they are more common". As examples of this issue, the recurrent use of adverbs ending in -mente or that of the periphrastic passive can be mentioned.

The influence of the English language on Spanish can also be felt in an interesting linguistic phenomenon: that of pseudo-Anglicisms or false Anglicisms. Balteiro Fernández $(2011)^{17}$ defines them as "words which are apparently of English origin but have actually been created elsewhere (...) or also those which, though originally English, have undergone important deviations and changes, mainly semantic and usage ones; in both cases the meanings may be at times unrecognizable for English native speakers". Therefore, as Campos-Pardillos $(2015)^{18}$ states, "precisely the influence of English on other languages is best proved not in those cases in which the use of a word would be 'logical,' i.e., where the item borrowed is a genuine English word, but in those proposals the success of which is merely due to their English-like appearance". Several taxonomies have been elaborated in relation to these "English-inspired" (Gottlieb and Furiassi, 2015) ${ }^{19}$ items. Out of them, the one by Furiassi (2010), ${ }^{20}$ quoted in Gottlieb and Furiassi (2015), ${ }^{21}$ seems to be the most comprehensive. According to it, pseudo-Anglicisms can be created in any of these ways:

- by joining two English free morphemes in order to form a compound that does not exist in English, e.g. recordman (record + man)

14 Vázquez-Ayora, Introducción a La Traductología: Curso básico de traducción.

15 For an analysis of concrete examples — along with Spanish equivalent proposals — illustrating this linguistic phenomenon, vide Araúz Gómez-Cadiñanos (1991).

${ }_{16}$ Rodríguez Medina, 'Los anglicismos de frecuencia sintácticos en español', 149.

${ }_{17}$ Balteiro Fernández, 'A Reassessment of Traditional Lexicographical Tools in the Light of New Corpora: Sports Anglicisms in Spanish', 28.

${ }^{18}$ Campos-Pardillos, 'All is not English that Glitters: False Anglicisms in the Spanish Language of Sport', 162.

${ }_{19}$ Gottlieb and Furiassi, 'Getting to Grips with False Loans and Pseudo-Anglicisms', 3.

${ }^{20}$ Furiassi, False Anglicisms in Italian.

${ }^{21}$ Gottlieb and Furiassi, 'Getting to Grips with False Loans and Pseudo-Anglicisms', 25-26. 
- by coining a new word based on an English free morpheme and an English suffix, e.g. footing (foot + -ing)

- by deleting the head of an English two-word compound, irrespective of the ellipsis rules of the English language, e.g. basket (from English basketball)

- by clipping a genuine English word, e.g. happy end (from English happy ending)

- by reusing an English word with a new meaning that is not found in English, e.g. mister (meaning in Italian 'coach' or 'trainer') $)^{22}$

— by employing English-looking proper names, e.g. carter (meaning in Italian 'chain guard' or 'crank case'), place names, e.g. new jersey (meaning in Italian 'median barrier' or 'traffic divider'), or trademarks, e.g. ticket restaurant, from genericised Ticket Restaurant $\mathbb{}($ (meaning in Italian 'meal ticket'), as common nouns.

In addition to all the types of English loanwords alluded above, which are frequently recorded in the literature, some authors add other kinds of Anglicisms, which should be mentioned despite they have received little examination.

Navarro (2008) makes reference to phonetic Anglicisms, explaining that, nowadays, there is a tendency to utter with an English-like pronunciation almost any word that looks foreign. He draws attention to typographic Anglicisms ${ }^{23}$ too, which he illustrates by means of four examples: the use of initial capital letters in all nouns and adjectives of book and chapter titles; the employment of Roman numerals in small letters for indicating the subsections in a text; the preference for dots before decimals and commas to point out thousand and million units; and the inclusion of a comma before Spanish conjunction $y$ at the end of an enumeration. ${ }^{24}$ Finally, this author mentions graphic Anglicisms, illustrating them by means of the following examples:

las listas de banderas colocadas, en publicaciones españolas, por orden alfabético del nombre en inglés del país correspondiente (...), en páginas internéticas españolas, el uso de iconos que reproducen un típico buzón estadounidense, con su banderita roja y todo, para indicar «correo electrónico», o que reproducen el eslabón de una cadena para indicar un hipervínculo o un enlace a otra página internética (en virtud, obviamente, del doble sentido de la palabra inglesa link, que tanto puede significar eslabón como enlace [...]) (p.230).

Navarro concludes his article by claiming that the anglicization of present-day Spanish goes beyond a mere list of calques and overt Anglicisms:; English is, in fact, exerting its influence on Spanish at every linguistic level.

22 The word mister is also used with this sense in Spanish.

${ }^{23}$ Rodríguez González (2002, pp. 130-131) includes the ampersand (\&) within the "typography" category.

${ }^{24}$ Rodríguez Medina (2000, p. 71) underscores the use of exclamation marks only at the end. She provides the following examples: "Viva! Las rebajas de El Corte Inglés" and "Revista Sorpresa!" (original italics).

25 As Pulcini et al. (2012, p.5) state, "moving beyond the analysis of individual lexical items, Englishinduced forms of borrowing seem to encompass a much wider range of phenomena than in the past, including larger phraseological units, idioms and proverbs. For this reason, some scholars suggest adopting a broader view of Anglicism in order to account for existing or emerging phenomena of Anglicization, and taking the term Anglicism as an umbrella label for any sign of interference - phonological, morphological, syntactic and 
Furthermore, the extralinguistic sphere is also affected by this foreign impact, as made clear by Lorenzo Criado $(1992)^{26}$ in his commentaries upon gestural Anglicisms. He refers to

los anglicismos gestuales que acompañan, como elementos paralingüísticos, a toda lengua, y que han penetrado, con ayuda del cine, en la televisión y la publicidad comercial: pulgar e índice formando un circulo, pulgar hacia abajo, pulgar hacia arriba, índice y corazón formando $V$, etc., y algún otro signo de la comunicación no verbal tan asidua y brillantemente estudiada por el profesor Fernando Poyatos, figura mundial en ese campo.

\subsection{Internationalisms}

Internationalisms deserve a section on their own because some authors (such as K. Heller, 1966 — quoted in Gómez Capuz, 1998, p.78-; Gómez Capuz, 1998; Görlach (ed.), $2001 ;{ }^{27}$ Rodríguez Díaz, 2011 ${ }^{28}$ ) do not comprise them within the traditional categories of loanwords, as will be explained in what follows.

In P. Wexler's (1969, p.77) words (quoted in Gómez Capuz, 1998, p. 80), an internationalism is "a word attested in a number of unrelated languages or language families, sharing a similar orthographic or phonemic shape and a partial or identical semantic field; most often, 'internationalisms' are of Greek or Latin origin". ${ }^{29}$ Thus, they form "a shared common stock", as Pulcini et al. (2012, p.4) point out. ${ }^{30}$

Moreover, Rodríguez Díaz (2011, p.85) highlights an idea expounded by Schmidt (1960): "se trata de palabras que se relacionan con el vocabulario técnico y científico ${ }^{31}$ cuyo

phraseological (but also semantic, pragmatic, stylistic and cultural) — which may be ascribed to the influence of the English language".

${ }^{26}$ Lorenzo Criado, 'La lengua española, hoy (VI). Anglicismos', 14.

27 Görlach, A Dictionary of European Anglicisms.

${ }_{28}$ Rodríguez Díaz, 'Anglicismos y germanismos en el lenguaje de la publicidad del español peninsular contemporáneo 1998-2007'.

29 As reported by P. Braun (1990, pp.27-29) — quoted in Gómez Capuz, 1998, pp.82-83—, on some occasions they have not been coined by using Classical material; they just come from an exotic language (on loanwords having an exotic language as "étimo ultimo", Pratt (1980) explains that they have entered European tongues via an intermediary language that has been in contact with both the exotic and the European ones, and which is normally English). Furthermore, Braun establishes another group of internationalisms according to etymological aspects: those originated in European languages, mainly French and English. An example of an internationalism coming from English is provided by Pulcini et al. (2012, p.4), who sustain that, once borrowed by the different recipient languages, it is "no longer easily recognizable as English in origin": "the phrase politically correct, politicamente corretto in Italian, politicamente correcto in Spanish, politiquement correct in French, politisch korrekt in German".

30 There are authors, such as Pratt (1980), who include the "anglicismos neológicos grecolatinos" (where the term "grecolatino" means "'derivado del latín', 'derivado del griego', y 'derivado del latín y griego"”) —Pratt, 1980, p.116 - within the category called "anglicismos neológicos absolutos".

31 W. Schmidt (1960) — quoted in Gómez Capuz, 1998, pp.79-80 — adds that the fields of culture, transport, and commerce are prone to have internationalisms in their specialised vocabularies. A. Iskos and A. Lenkova 
material lingüístico puede adscribirse etimológicamente a alguna lengua de cultura pero que mantienen un carácter internacional".

Due to the fact that they constitute "a form of interlinguistic contact" (Pulcini et al., 2012, p.4), some authors such as Gómez Capuz (1998, pp.78-83) consider them not to be included within the traditional borrowing categories. He explains this point by stating that (1) the process that takes place in these cases is a multilateral rather than a bilateral one: there is a donor language and a series of receiving tongues (instead of just one); and (2) sometimes it is impossible to discover the identity of the source language. ${ }^{32}$ However, statement (1) could be counterargued if dividing the complex process into isolated borrowings from the model language to each receptor tongues. From this point of view, the same word has been involved in several independent bilateral processes from a model language to various recipient tongues. In relation to (2), it is relevant to bring up an idea set out by Görlach (2003, p.56): "most of the neo-Greek/Latin words are truly international, carrying in them no trace of the nation that coined them —unless we have extralinguistic evidence to go by". These extralinguistic factors are indeed argued for considering English as the originator of these words by authors like Pratt (1980). As Gómez Capuz (1998, p.83) sketches it, "algunos autores reconocen el predominio del inglés norteamericano en la acuñación y difusión de todo tipo de internacionalismos, incluidos los de apariencia grecolatina, debido a la hegemonía norteamericana en el mundo actual".

Examples of internationalisms are:

—Eng. telephone, Sp. teléfono, Fr. telephone, Por. telefone, It. telefono, Germ. Telefon; - Eng. photograph, Sp. fotografía, Fr. photographie, Por. fotografia, It. fotografia, Germ. Fotografie;

—Eng. megahertz, Sp. megahercio, Fr. megahertz, Por. megahertz, It. megahertz, Germ. Megahertz;

—Eng. genome, Sp. genoma, Fr. génome, Por. genoma, It. genoma, Germ. Genom.

As these illustrations show, every language adapts these words to its phonetic, orthographic and morphological peculiarities ${ }^{33}$, but nonetheless, they are easily understandable for speakers of the other tongues (K. Heller, 1966, pp.36-37 — quoted in Gómez Capuz, 1998, p.81-). Considering the original language in which these internationalisms were coined (i.e. the tongue that took Classical linguistic material to name a new technical or scientific discovery/invention), a difference is glimpsed between examples 1, 2, and 3, on the one hand, and number 4 , on the other hand. When searching for these words in the $23^{\text {rd }}$ edition of the Diccionario de la Lengua Española (RAE, 2014), the following etymological data are found:

(1960, p.104) —also quoted in Gómez Capuz, 1998, pp.79-80 - mention economics, politics, arts, and everyday life as areas to which internationalisms can be attached as well.

32 The impossibility to find out the original language where the term arose is defended by scholars such as W. Schmidt (1960) and Wexler (1969), as Gómez Capuz (1998, p. 82) indicates.

${ }^{33}$ It is interesting to note that, in the third example, only the Spanish language has adapted the word; in the rest of the tongues it remains formally equal. 
— teléfono: "De tele- ${ }^{1}$ y -fono".

— fotografía: "De foto- y -grafía".

— megahercio: "De mega- y hercio".

— genoma: "Del al. Genom, de Gen 'gen' y -om '-oma".

Therefore, according to the piece of information contained in the Academic Dictionary, "teléfono", "fotografía" and "megahercio" do not have a clear filiation, since the only datum provided about them refers to their constituents (i.e. the elements forming them). These three cases seem to confirm the idea, asserted by scholars such as W. Schmidt (1960) and Wexler (1969) —quoted in Gómez Capuz (1998, p. 82)—, that it turns out to be very hard to discover the language in which the word was coined. However, "genoma" illustrates the opposite: the DRAE provides us with the specific provenance "from German Genom".

Finally, it can be concluded that these items are diffused as "pilgrim word[s] into a range of languages" (T. Mc Arthur, 1991 — quoted in Gómez Capuz, 1998, p.79—), thus becoming an international lexical phenomenon (Rodríguez Díaz, 2011, p.87).

\section{DEFINITION OF THE TERM ANGLICISM}

The very term Anglicism is not exempt from controversy. For Pratt (1980), ${ }^{34}$ Anglicisms are only those words whose "étimo inmediato" (i.e. the language from which they have been taken directly, no matter the languages in which it has been employed in its previous history; vs. "étimo último", the first and most remote language in which the word was coined, normally Latin or Greek) is the English language. On the contrary, Lorenzo Criado (1996) ${ }^{35}$ collects words that come from English, directly or through other languages. Among the definitions proposed so far, the one put forward by Gottlieb $(2005)^{36}$ should be highlighted, because it covers both the concepts of true and false Anglicisms: "any individual or systemic language feature adapted or adopted from English, or inspired or boosted by English models, used in intralingual communication in a language other than English". The definition of the term Anglicism that I propose in the present piece of research results from completing the one I have just referred to:

Any linguistic element adopted, adapted or calqued from English (either directly or via an intermediary tongue), or inspired or boosted by English models, used in intralingual communication in a language other than English.

\footnotetext{
${ }^{34}$ Pratt, El anglicismo en el español peninsular contemporáneo.

35 Lorenzo Criado, Anglicismos hispánicos.

${ }^{36}$ Gottlieb, 'Anglicisms and Translation', 163.
} 


\section{TYPOLOGY PROPOSAL}

Since the classifications suggested so far are characterized by dealing with only a part of the phenomenon (each of them with a different area, but all lacking a global scope), I attempt to propose a comprehensive and complete typology of linguistic Anglicisms in the Spanish language, which will be obtained by reconsidering the ones previously established by other scholars (vide supra, section 2), combining several suggestions out of those they have made, selecting the most suitable and clearer labels, and raising the question of whether any new category should be added. ${ }^{37}$ This way, it will be possible to structure a coherent taxonomy that takes into account the numerous kinds of Anglicisms that are currently employed in Spanish.

In order to clarify the structure this classification will have, I display it in a table format -including examples for every category — before explaining each of the various types that it contains (vide Table 2).

TABLE 2.

Typology proposal

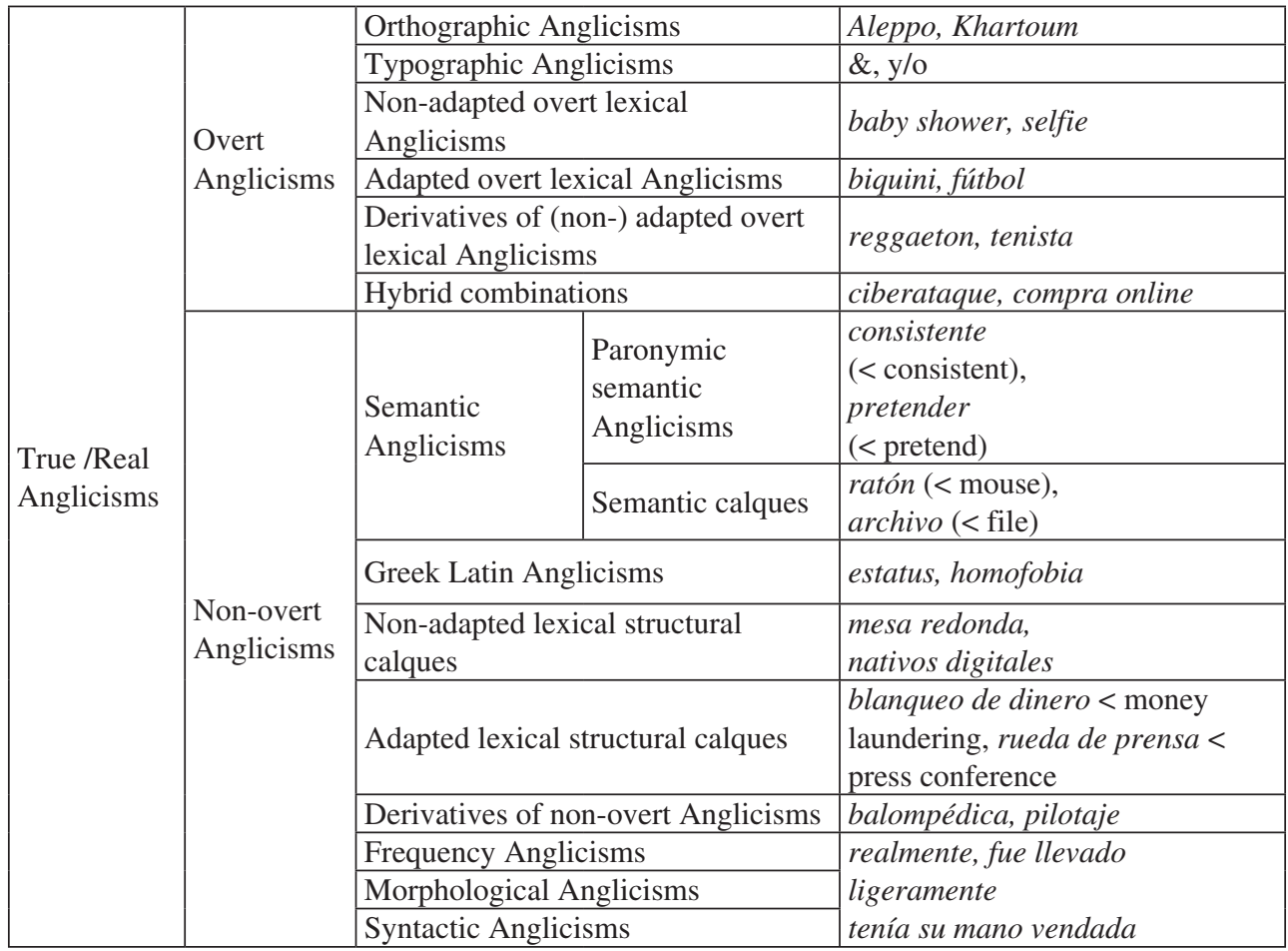

37 It must be clarified that, in the present article, I focus on the types of Anglicisms that are employed nowadays in the Spanish language, leaving aside the pragmatic effects they may convey. 


\begin{tabular}{|c|c|c|}
\hline \multirow{10}{*}{$\begin{array}{l}\text { False } \\
\text { Anglicisms } \\
/ \\
\text { Pseudo- } \\
\text { Anglicisms }\end{array}$} & Autonomous compounds & $\begin{array}{l}\text { recordman (record + man), } \\
\text { aeroclub (aero + club) }\end{array}$ \\
\hline & English free morpheme + English suffix & $\begin{array}{l}\text { footing (foot }+ \\
<\text { ing) } \\
\end{array}$ \\
\hline & Spanish root / free morpheme + English suffix & $\begin{array}{l}\text { puenting (puent- + -ing), } \\
\text { balconing (balcon + -ing) }\end{array}$ \\
\hline & Truncated Anglicisms & christmas, portátil \\
\hline & Clippings & $\begin{array}{l}\text { happy end } \\
\text { (< happy ending), kitesurf } \\
(<\text { kitesurfing })\end{array}$ \\
\hline & $\begin{array}{l}\text { Spelling of the Spanish pronunciation of an } \\
\text { English initialism'38 }\end{array}$ & cedé, elepé \\
\hline & Assigning a new meaning to an English signifier & $\begin{array}{l}\text { book 'álbum de fotos' } \\
\text { box 'zona de asistencia técnica' }\end{array}$ \\
\hline & Misinterpretation & aeróbic, marshall \\
\hline & Word-class change & $\begin{array}{l}\begin{array}{l}\text { multitask (verb) }>\text { multitarea } \\
\text { (noun) }\end{array} \\
\end{array}$ \\
\hline & Trademark turned into a common noun & $\begin{array}{l}\text { iPad, explorador }(<\text { Internet } \\
\text { Explorer })\end{array}$ \\
\hline
\end{tabular}

First of all, a distinction is made between true and false Anglicisms. The former are characterized by being adoptions (or adaptations, or calques) of real English words that are employed in the source language; the latter consist of coinages that have been invented in languages other than English but using English elements, giving as a result words that are not used in English, or at least not in the same way or with the same meaning.

True/Real Anglicisms ${ }^{39}$ are divided into overt and non-overt ones - in these two broad categories I follow Pratt's (1980) terminology: anglicismos patentes y no patentes. Those loans belonging to the first group are clearly recognisable as foreign words in the receptor language, whereas the ones under the second label go unnoticed due to their Spanish appearance.

Within overt Anglicisms, six different types are distinguished. Orthographic Anglicisms concern spelling issues connected to the transliteration of words that originate in a non-Latin script language, mainly Arabic or Russian. Gómez Capuz (1992), ${ }^{40}$ defines "anglicismo ortográfico" as "la transliteración de un nombre propio - topónimo o antropónimo- de una lengua que no emplea el alfabeto latino (ruso y árabe sobre todo) conforme a las reglas ortográficas y fonémicas del inglés y no a las del español". This author points out that Spanish newspaper offices receive these exotic names already transliterated according to

\footnotetext{
${ }^{38}$ Initialism: (noun) "An abbreviation consisting of initial letters pronounced separately (e.g. BBC)" (Oxford Dictionary).

39 Vide Furiassi and Gottlieb (2015). Other terms to name this reality are "proper Anglicisms", "genuine Anglicisms", and "authentic Anglicisms" (Balteiro Fernández, 2011, 31-32).

${ }^{40}$ Gómez Capuz, 'Anglicismos en las noticias sobre la Guerra del Golfo Pérsico', 302.
} 
the Western intermediary languages ${ }^{41}$ rules. Since Gómez Capuz (1992) focuses on the news related to the Persian Gulf War, the examples he provides come from Arabic. Some of them are Aleppo, Khartoum, Al Saghir and Abu Dhabi.

With the label typographic Anglicisms, several elements are referred to: the use of the English character \& in the Spanish language (Rodríguez González, 2002) ${ }^{42}$, the capitalisation of initials in titles and headings (Rodríguez González, 2002; Navarro, 2008), "the occasional use of the slash to indicate a disjunctive, $y / o$ from E[nglish] and/or (Lorenzo, 1988)" (Rodríguez González, 2002, p.131), the appearance of (1) "comma instead of decimal point to separate thousands", (2) "decimal point instead of the comma for decimals", (3) "capital letters for nationalities, weekdays, etc." (Ferro, 2014), ${ }^{43}$ the use of exclamation marks (Rodríguez Medina, 2000 - vide note 23$)^{44}$ and question marks only at the end, and other similar elements which are dealt with in a brief and very interesting article by Martínez de Sousa (2003), ${ }^{45}$ who stresses the importance of translation as a path for the entrance of Anglicisms.

Non-adapted overt lexical Anglicisms are those which have been introduced into the receiving language without any change in their form. Thus, the original spelling is not modified at all. The following loanwords are examples of this category: baby shower, feedback, robot, selfie, tablet $^{46}$

The label adapted overt lexical Anglicisms refers to the cases that have been adapted to the orthographic and/or morphological rules of the recipient language, such as bádminton, biquini, coctel, estándar, fútbol, pedigrí.

Derivatives of overt Anglicisms are words that have been formed in the recipient language as derivatives of overt English lemmas that entered before. Thus, they consist of an

${ }^{41}$ English or French, depending on the areas of their former colonial dominion.

42 Rodríguez González, 'Spanish'.

43 Ferro, 'An Analysis of Anglicisms in the Sports Sections of Granma and El Nuevo Herald', 122. This author refers to these cases as "ortho-typographic Anglicisms", which is the same term employed by Martínez de Sousa (2003).

${ }^{44}$ Rodríguez Medina, 'Los anglicismos de frecuencia sintácticos en los manuales de informática traducidos', 71.

45 Martínez de Sousa, 'Los anglicismos ortotipográficos en la traducción'.

${ }^{46}$ Among the non-adapted overt lexical Anglicisms there is a special group that is formed by very few cases, as Pratt (1980) indicates: "son poquísimos los anglicismos registrados que están compuestos enteramente por grafías acordes con la estructura ortográfica española (como sidecar, por ejemplo)” (p.128), “[e]1 reducidísimo número de formas cuya estructura originaria concuerda con las pautas ortográficas del español (...)” (p.149). These Anglicisms have maintained their original English form in the recipient language; therefore, since they have undergone no orthographic or morphological adaptation (although, in terms of pronunciation, some modifications have taken place), they are to be classified as non-adapted overt lexical Anglicisms. However, they do not fulfil the criterion of being identifiable as foreign elements; in fact, they could be said to be Spanish words if only form was considered. Some instances of this particular group of Anglicisms are bar, rifle, safari, sidecar, transistor and suspense. 
English root and a Spanish affix. Boicoteadores, goleada, reggaeton ${ }^{47}$ and tenista are examples of this group.

Lastly, hybrid combinations are multiword units formed by two elements, one of which is English and the other one, Spanish. ${ }^{48}$ For instance, ciberataque, compra online, hockey sobre hielo, navegador web, and Open Británico. Although the inclusion of this type of Anglicism in the overt group can be controversial, since half of it remains in its original English form (either as non-adapted or as adapted overt lexical Anglicisms) but the other part has been translated —otherwise termed "semi-calques"49 (Alexieva, 2002;50 Stathi, 2002; ${ }^{51}$ Maximova, 2002; ${ }^{52}$ Busse \& Görlach, 2002;53 Pulcini, 200254)—, I will follow in this point Alejo González (2002), ${ }^{55}$ who classifies this type of loan among the "anglicismos patentes", because it retains an element “de grafía inequívoca inglesa” or, in Pulcini et al.'s $(2012)^{56}$ words, "the English component of their lexical make-up is still visible".

With respect to non-overt Anglicisms, I will follow Pratt (1980) in relation to the first group, namely semantic Anglicisms (Pratt calls them traditional words). It is divided into two categories: paronymic ${ }^{57}$ semantic Anglicisms, on the one hand, and semantic calques, on the other hand. In the case of paronymic semantic Anglicisms, the meaning of a traditional Spanish word is affected by the English influence (the word acquires a new sense, a sense its English paronym has. This transfer takes place due to the formal similarity shared by both words). For instance, Spanish eventualmente has acquired the sense 'finally' that the English word eventually has. As far as semantic calques are concerned, the English model is translated, and there is no direct etymological relationship between the English word and its Spanish translation, although they can have the same "étimo último"58 (for example, to channel/canalizar). Despite the fact that, in this case, there is no formal similarity between the English and the Spanish words, they already share one meaning (a literal one), and this makes it feasible to transfer another one (a figurative sense) from the English to

${ }^{47}$ DRAE, 23 ${ }^{\text {rd }}$ ed.: reguetón: "De reggaeton, término acuñado por el panameño M. Ellis en los años ochenta del siglo XX, y este del ingl. reggae 'reggae' y -ón"”.

${ }^{48}$ In the classification I propose, hybrids are always multiword units. On the contrary, Gómez Capuz (1992) illustrates this category by means of cases in which there is a combination of an English imported base and a Spanish affix: liderazgo, boicoteo (p.315). In the taxonomy I expound in the present article, these instances would be considered as derivatives of overt Anglicisms.

49 I refer here to lexical structural calques rather than semantic ones (vide infra).

50 Alexieva, 'Bulgarian', 256.

51 Stathi, 'Modern Greek', 324.

52 Maximova, 'Russian', 208.

53 Busse \& Görlach, 'German', 29.

54 Pulcini, 'Italian', 163.

55 Alejo González, 'Influencia del vocabulario económico inglés sobre los textos de economía españoles posteriores a la II Guerra Mundial', 216-17.

${ }^{56}$ Pulcini, Furiassi, and Rodríguez González, 'The Lexical Influence of English on European Languages. From Words to Phraseology', 10.

${ }^{57}$ I translate the Spanish word "parónimo" employed in Pratt (1980) by the English term "paronym". Note that I use the term "paronym" in its sense "a cognate word" (Collins Dictionary).

58 The term "étimo último" refers to the first and most remote language in which the word was coined, normally Latin or Greek (Pratt, 1980). 
the Spanish language. For instance, the English word mouse corresponds to Spanish ratón in the sense of 'a small long-tailed rodent'. When the English word mouse was added a new sense (in the field of computing rather than zoology), that of 'a hand-held device used to control the cursor movement and select computing functions without keying' ${ }^{59}$ - due to the shape similarity that exists between the animal and the device-, this new meaning was transferred to its Spanish equivalent ratón.

The term Greek Latin Anglicism is included by Pratt (1980), who defines it as " 'derivado del latín', 'derivado del griego' y 'derivado del latín y griego' ” (p.116). However, he does not consider it as a category on its own. With the purpose of simplifying the complex structure that this author lends to the group he names "neological words" (vide section 2) and in order to clarify this kind of Anglicisms, I will make use of the term Greek Latin Anglicism to refer to those simple words (for example, estatus, habitat, vinilo ${ }^{60}$ ) and also compounds that have been coined in English (or in French and adopted by English afterwards, such as helicóptero and infraestructura), and in which either both or just one of the parts forming $\mathrm{it}^{61}$ come(s) from a classical language (for instance, endogamia, homophobia, internet, megavatio). These words name new and modern concepts which either did not exist or, at least, were not verbalized in the Classical World. In relation to this phenomenon, Pratt (1980) alludes to Modern Latin, ${ }^{62}$ that is, the present-day use of Latin elements that are resorted to in the English tongue in order to denominate new realities. The fact that it is the English language that has coined these terms (most of them date from the $18^{\text {th }}$ century onwards) by using classic material should be specified when referring to the etymology of these words once they have entered Spanish. Otherwise, as Pratt (1980, p.45) alerts, misleading data can be sent out. By paying attention to the piece of information provided by the $23^{\text {rd }}$ ed. of the DRAE on the word "megáfono" ("De mega- y - fono"), for instance, it could be thought that this device was named in Spanish. Thus, the importance of providing data on the language that coined the term should be taken into consideration, as this simple example illustrates.

The concept of internationalism must be put forward at this moment for the sake of clarification. It was dealt with in section 2.1., where the frequent English provenance of these words was explained by emphasising the supremacy of the United States with respect to technological and scientific developing. Inasmuch as most internationalisms are made up of Classical-origin elements, and have been coined in the English language, I will consider them as Greek-Latin Anglicisms. As concerns those exotic terms (such as kimono, samurai, balalaika, sake) that have spread among different tongues and therefore belong to the category of internationalisms, I will treat them as any other loanword having an exotic language as "étimo último" (the fact is that an internationalism is a word that has undergone various borrowing processes to different languages; thus, the linguistic procedure is the same, ei-

\footnotetext{
${ }^{59}$ http://www.collinsdictionary.com/dictionary/english/mouse [accessed 25/10/2016].

${ }^{60}$ DRAE, 23 $3^{\text {rd }}$ ed.: vinilo: "Del ingl. vinyl, y este del lat. vinum 'vino' y el ingl. - $y l$ '-ilo'".

${ }^{61}$ Derivative words with a classical affix are also comprised within this category.

${ }^{62}$ The same can be asserted about Greek; nevertheless, the term Modern Greek will not be employed here to avoid misunderstandings in relation to the language currently spoken in Greece.
} 
ther happening just once from a language A —in these cases, the "étimo inmediato" would be English - to a language B, or several times, from language A to B, from A to C, from A to D...; for instance, from English to Italian, from English to Spanish, from English to Dutch...).

To continue with non-overt Anglicisms, the category of lexical structural calques (Gómez Capuz, 2005, pp.36-41; vide section 2, note 10$)^{63}$ should be delved into. They are the items that result from translating English multiword units. Although the words already existed independently in Spanish before, their combination means a new coinage created by the English influence. This type of Anglicism can be of two kinds: non-adapted lexical structural calques and adapted lexical structural calques. Under the former label, those structures whose constituents are the literal translations of the elements forming the original English compound are grouped (for example, agujero negro, mesa redonda, nativos digitales). The latter term refers to the cases where there has been a modification — a formal rather than a semantic one- when translating the donor language form (blanqueo de dinero < money laundering, rueda de prensa < press conference) ${ }^{64}$. Some lexical structural calques have been created ad hoc in Spanish to avoid using an overt Anglicism, such as the compound balompié.

The label derivatives of non-overt Anglicisms subsumes those words that have been formed in the receptor language as derivatives of non-overt English items that entered before. The words balompédica and pilotaje are instances of this kind of loan.

Frequency Anglicisms are those elements that are considered as Anglicisms when they are employed in a recurrent way. Thus, they are not loanwords by themselves; they do exist in Spanish, but are used in this language much less commonly than they are in English. Consequently, it is their frequent appearance due to the English influence that makes them being regarded as Anglicisms. In Vázquez-Ayora's (1977, p.103) words, "su repetición en el uso no es castiza". This phenomenon implies the leaving aside of other Spanish forms of expression that could alternate with the English-influenced one. As Lorenzo Criado (1996, p.616) declares, "[se] prescinde de las ricas posibilidades matizadas y expresivas de que dispone nuestra lengua, y [se] favorece el empobrecimiento que tan justamente lamentan quienes de veras admiran la riqueza significativa del español". Furthermore, he adds that these Anglicisms are not "censurables ni condenables por infracción de reglas o normas jamás establecidas, pero sí por la frecuencia y exclusividad con que desplazan e incluso arrinconan fórmulas de expresividad y eficacia demostradas" (Lorenzo Criado, 1996, p. 617). Subsequently, as this author clarifies, "al excluir otras opciones que ofrece la lengua espa-

\footnotetext{
${ }^{63}$ Whereas Gómez Capuz (2005) names this type of loan with the labels lexical calques or structural calques, I have decided to unify the two options as lexical structural calques for clarification purposes.

${ }^{64}$ It is interesting to note the case of "rascacielos". When being translated, the English compound form "skyscraper" underwent a slight but curious modification: the Spanish second part of the term was fixed as "cielos", whereas the original corresponding element is 'sky' (rather than 'skies'). To be completely faithful to the original form, the Spanish version should have been fixed as "rascacielo".
} 
ñola, suenan, por su insistencia, extraños y monótonos" (Lorenzo Criado, 1987, p.74, quoted in Rodríguez Medina, 2000). ${ }^{65}$

Thus, frequency Anglicisms are, as Stockwell, Bowen, and Martin (1965, p.276, quoted in García González, 1997-1998) ${ }^{66}$ claim, "grammatically impeccable but they nevertheless lack "native quality' ". Indeed, the recurrent use of these elements due to the English influence does not entail a formal but a stylistic mistake (Gómez Capuz, 1992; Vázquez-Ayora, 1977).

This linguistic phenomenon of frequency Anglicisms has been delved into within the framework of translation studies by several authors. Vázquez-Ayora (1977) provides pieces of advice on how to avoid this foreign influence when translating from English into Spanish (i.e. how to prevent features of the source language text from affecting the text that is produced in the target language). He claims that there are lexical as well as structural ${ }^{67}$ frequency Anglicisms. ${ }^{68}$ Meanwhile, García González (1997-1998) focuses specifically on journalistic translation. ${ }^{69}$ In the concluding section of his study, he claims that

hay que destacar que el modo de expresión periodístico tiende a potenciar el uso de ciertas construcciones con el objetivo de imprimir al contenido un tono más neutro, impersonal y solemne que le dé credibilidad. Algunas de estas posibilidades gramaticales (...) son de uso bastante más frecuente en inglés. Desde este (sic) perspectiva, y teniendo en cuenta que se trabaja con textos traducidos, la presencia usual de este tipo de estructuras para traducir las inglesas puede incluirse en el campo de los anglicismos. Sin embargo, esta influencia del inglés queda en ocasiones encubierta o tolerada por la difusión que tienen en el lenguaje periodístico algunas de estas formas de expresión frente a otras alternativas posibles en español (pp.619-620).

Although, as can be read above, there are authors — such as Lorenzo Criado (1996), Vázquez-Ayora (1977), and Araúz Gómez-Cadiñanos (1991) — who divide frequency Anglicisms into lexical ones and structural/syntactic ones, I will consider them as morpho-syntactic, following García González (1997-1998), ${ }^{70}$ since those that have been classified by these scholars as lexical do factually appear at a morphological or a syntactic level. This way, the discontinuous lines which separate frequency, morphological, and syntactic An-

\footnotetext{
${ }^{65}$ Rodríguez Medina, 'Los anglicismos de frecuencia sintácticos en los manuales de informática traducidos', 201.

${ }^{66}$ García González, 'Anglicismos morfosintácticos en la traducción periodística (inglés-español): Análisis y clasificación', 598.

${ }^{67}$ By using "structural" the author means "syntactic".

${ }^{68}$ Araúz Gómez-Cadiñanos (1991), also locating his research within the translation field, adopts VázquezAyora's classification into lexical and structural frequency Anglicisms.

${ }^{69}$ The foreign (mainly English) origin of many pieces of news that arrive to Spanish newspapers from news agencies makes it compulsory to translate them, being the final product the reader finds not an original text but a translated one.

${ }^{70}$ García González (1997-1998, p.595, note 1) defines "anglicismo morfosintáctico" as "la influencia o huella del texto en la lengua de partida (inglés) sobre el texto en la lengua de llegada (español) en los niveles morfológico y sintáctico en concreto".
} 
glicisms in Table 2 reflect that these three kinds of non-overt Anglicisms are connected to a certain extent. They overlap on some occasions, as will be examined in the following pages.

In relation to the morphological ones, they should be considered as frequency Anglicisms as well, because the cases covered by the morphological label are grammatically correct in Spanish, being the English influence felt only when they are recurrently employed. This category only comprises adverbs ending in '-mente'.

Indeed, due to the common use of the suffix '-ly' in English to form adverbs, its Spanish translation '-mente' is undergoing an increase in its frequency of appearance (Vázquez-Ayora, 1977; García González, 1997-1998; Rodríguez Medina, 200271). As García González (1997-1998, p.615) points out, this limits "el empleo de otros adverbios y perífrasis equivalentes que son bastante productivos en español". In regard to this point, Rodríguez Medina (2002, p.153) highlights the alternative consisting of the modification of the verbal action by means of complements like "de forma/manera + adjetivo", whereas Vázquez-Ayora (1977) provides us with a long list of adverbs, each of them accompanied by a prepositional phrase or a periphrasis that can substitute the form ending in '-mente'.

As for syntactic Anglicisms, Pratt (1980) and Rodríguez Medina (1998-1999, ${ }^{72} 2000$, 2002) distinguish between two groups:

- Those syntactic structures that do exist in Spanish but whose frequency of use is lower than it is in English. Due to the influence of this foreign tongue, they are now more commonly employed in the recipient language. Pratt (1980, p.209) names this phenomenon "ampliación de uso de la estructura preexistente", which corresponds to the previously explained concept of frequency Anglicism (Vázquez-Ayora, 1977; Lorenzo Criado, 1996; Rodríguez Medina, 1998-1999, 2000, 2002)

- Those syntactic constructions that emerge in the Spanish language as a result of calquing English structures which did not exist in Spanish before. While Rodríguez Medina (1998-1999, p.397) called them "interferencias", in her works dated 2000 (p.200) and 2002 (p.151) she changes the term employed for this phenomenon, stating that it is labelled "innovación sintáctica" (although she does not specify that the scholar who coined this name was Pratt, 1980, p.210).

Syntactic Anglicisms of frequency ${ }^{73}$ (the first of the two groups mentioned above) can be illustrated by means of the cases that will be described in what follows ${ }^{74}$ :

\footnotetext{
${ }^{71}$ Rodríguez Medina, 'Los anglicismos de frecuencia sintácticos en español'.

${ }^{72}$ Rodríguez Medina, 'Anglicismos sintácticos en el sistema preposicional español: El caso de los manuales de informática traducidos'.

${ }^{73}$ I have found this term in Rodríguez Medina (2000 and 2002).

${ }^{74}$ A common route of entry for this kind of Anglicism into Spanish is the translation of English texts, such as the pieces of news that arrive to Spanish media from foreign news agencies on a daily basis. Typical English structures are transferred to the target text every single time they appear, and their recurrent encounter in these translated texts creates a favourable atmosphere for their subsequent independent use (i.e. when there is no English source text acting as a model).
} 
- The overuse of nominalisations (with this term I refer to Spanish verbal actions that are conveyed by means of nouns because that is the form in which they are expressed in English). Vázquez-Ayora (1977, pp.129-131) sustains that the Spanish language is characterised by its verbal vigour, while English shows a clear preference for nouns. Therefore, in the field of translation, a Spanish target text in which all English source text nouns have been translated by nouns can give off a sense of coolness and monotony, of stillness, something that does not correspond to the dynamism that is typical of the Spanish language (Araúz Gómez-Cadiñanos, 1991). This does not mean that on every occasion any English noun should be turned into a verb in Spanish. Achieving a proper balance is thus indispensable. Nevertheless, translators must keep in mind that an excessive use of nouns will yield the text a foreign style.

— The increasing use of pre-modifying adjectives complementing a noun ("adjetivos calificativos") to the detriment of post-modifying ones, especially in technical texts, where the latter should be preferred in Spanish. For more on this complex issue, vide, among others, Vázquez-Ayora (1977), García González (1997-1998), and Rodríguez Medina (2002).

- Some uses of the gerund in contexts where non-verbal constructions would be more stylistically suitable. This occurs due to the effect that the high variety of functions fulfilled by English -ing forms exerts over the Spanish language (García González, 1997-1998; Rodríguez Medina, 2002).

— The recurrent use of the passive voice with the verb "ser" (pasiva perifrástica) ${ }^{75}$ Vázquez-Ayora, 1977; Pratt, 1980; Medina López, 2004 [1996]; Gómez Capuz, 1992; García González, 1997-1998; Rodríguez Medina, 2000, 2002—. As Lorenzo Criado (1996, p.487) defends, “[1]a difusión de este tipo de oraciones, favorecida por la prosa periodística, influida por noticias de agencia procedentes de inglés, tiene el terreno abonado por el esnobismo involuntario de muchos". Certainly, the active voice as well as the "pasiva refleja"76 are preferred in Spanish: "Dicho queda que el español puede usar la pasiva con ser cuando libremente lo prefiera, pero está claro que libremente no lo hace, a menos de estar influido, en mayor o menor grado, por la prosa inglesa" (Lorenzo Criado, 1996, p.623 — original italics).

- The excessive use of clause coordination or juxtaposition (parataxis) —Vázquez-Ayora, 1977-, which is furthermore accompanied by unnecessary and unjustified repetitions of words and structures. In this respect, Rodríguez Medina (2002, pp.154-155) quotes García Yebra (1984, p. 372):

En el discurso inglés, a diferencia del español, debido a la ausencia de elementos desambiguadores como el género, a la menor capacidad de la flexión verbal y a la pobreza del sistema

\footnotetext{
75 I include within this group the passivisation of the Spanish verbal periphrasis "estar + gerundio" (i.e. the structure "estar + siendo + participio pasado") in order to comprise all passive forms within the same group of Anglicisms (i.e. syntactic Anglicisms of frequency). Pratt (1980, p.210), on the contrary, classifies this specific case -i.e. "estar + siendo + participio pasado" - among the instances of "la innovación sintáctica".

${ }^{76}$ DRAE, 23 ${ }^{\text {rd }}$ ed.: pasiva refleja: "1. f. Gram. Oración de significado pasivo constituida por un sujeto paciente en tercera persona, un verbo transitivo y la forma pronominal se; p. ej., Se venden dulces".
} 
deíctico, se tiende a repetir los términos de forma muy frecuente en oraciones cortas, lo que aumenta la disposición paratáctica las secuencias. Por esta razón, abunda, en la lengua anglosajona, la yuxtaposición, mientras que, en español, se prefiere la subordinación, es decir, la organización sintáctica dominante es la hipotaxis.

- The repetitive use of the auxiliary verb "poder" when translating the English modal verbs can, could, may, and might. In some contexts, an alternative would be the omission of the form (Rodríguez Medina, 2002, p.165, includes some examples, such as "incluso si no lo puede ver en la pantalla" $\rightarrow$ "incluso si no lo ve en la pantalla"; vide Pratt, 1980, p.209 as well). On other occasions, as Lorenzo Criado (1996, pp.634-635) indicates, the Spanish language is able to convey the same meaning by means of the subjunctive (vide Vázquez-Ayora, 1977, and García González, 1997-1998 too).

— The overuse of the order "subject + verb + object" (Vázquez-Ayora, 1977). English sentences are characterised by the fixed order of their constituents. On the contrary, the Spanish language is distinguished by its flexibility in this respect, allowing therefore a wide variety of order arrangements (Lorenzo Criado, 1996). Among them it is, of course, the "subject + verb + object" sequence. However, when -in the field of translation - this one is transferred invariably to a Spanish target text, the final product is pervaded with a foreign atmosphere. Moreover, in the case of pronominal subjects, as Vázquez-Ayora (1977, p.105) stresses, "todo sintagma verbal completo, salvo el imperativo, lleva sujeto expreso en inglés. En español, cuando el sujeto está implícito en el contexto no es necesario expresarlo. Las desinencias personales de la conjugación española (...) casi siempre hacen innecesario su empleo". This way, the author warns that "la repetición insistente de los sujetos pronominales puede traer un matiz de énfasis o agresividad, aparte de la pesadez que comunica al estilo" (p.105).

- The recurrent use of the construction "demasiado + adjetivo + como + para" (Vázquez-Ayora, 1977; Araúz Gómez-Cadiñanos, 1991)

To conclude this section on frequency Anglicisms, I will quote two fragments included in Lorenzo Criado (1996), which suitably summarise what has been dealt with in the previous paragraphs: "Estos usos frecuentes, que son, por lo regular, opciones legítimas de la lengua, cabe considerarlos huellas del inglés, si comparamos textos escritos espontáneamente en español con otros traducidos" (pp.630-631). "Los traductores, al elegir entre distintas correspondencias sintácticas del español, optan por la más parecida al inglés, desplazando así otras aparentemente sinónimas y empobreciendo la expresión” (pp.201-102).

On the other hand, there are syntactic structures that did not exist previously in Spanish and have emerged as a result of the formal literal translation (i.e. the calquing) of English constructions. The following cases belong to this second group of syntactic Anglicisms: ${ }^{.7}$

77 The phrase consisting of the adverb 'no' + noun was accepted by the Real Academia Española in the Ortografía de la lengua española (2010), pp.542-543 [Online edition (www.rae.es). Accessed on 31-10-2016]; therefore, it will not be considered as an incorrect form in Spanish any more. 
- Prepositions:

- employed in verb + preposition / adjective + preposition collocations (*difícil a hacer —Pratt, 1980— ${ }^{78} *$ consistir de —Rodríguez Medina, 1998-1999— ${ }^{79}{ }^{*}$ esperando por Antonio (waiting for) —Medina López, 2004 [1996]— ${ }^{80}$ ).

— used in temporal turns of phrase (*No le había visto por un año —Pratt, 1980— ${ }^{81}$ )

- omission of prepositions which are necessary in Spanish (*jugar tenis - Estrany Gendre, 1970;82 Pratt, 1980;83 vide Rodríguez Medina, 1998-1999 ${ }^{84}$ and Lorenzo Criado, $1996^{85}$ as well $)^{86}$

— The usage of possessives with body parts, articles of clothing, and similar elements in contexts where the Spanish language would naturally employ other structures, such as reflexive constructions combined with definite articles. For instance, the English sentence I have brushed my teeth this morning should be translated as Me he lavado los dientes esta mañana, in lieu of the literal translation *He lavado mis dientes esta mañana. Since the latter option goes against Spanish grammar rules, I have decided to include this point within the group of previously non-existing structures in Spanish, although several authors I have consulted locate it along with the cases of frequency Anglicisms (Vázquez-Ayora, 1977; Pratt, 1980). Notwithstanding this, it should be acknowledged that there are some specific contexts in Spanish where a possessive can accompany objects such as pieces of clothing and accessories, for example, as in Le encantaba ponerse su chaqueta negra or Recuerdo haberlo visto en la cafetería de la facultad con su sombrero. García González (1997-1998) $)^{87}$ aptly clarifies that "se recurre al posesivo en estos casos para expresar distintos matices afectivos o enfáticos". Therefore, these special specific cases do not justify the inclusion of the (general) use of possesives with body parts, articles of clothing, and similar elements within the frequency Anglicisms type.

—Articles. Vázquez-Ayora (1977) and García González (1997-1998) shed light on this issue, making clear that, in several cases, there is no direct correspondence between the use of definite, indefinite, and zero articles in English and Spanish. These authors provide translators with pieces of advice on how to avoid the appearance of syntactic Anglicisms in relation to this linguistic element.

\footnotetext{
78 Pratt, El anglicismo en el español peninsular contemporáneo, 210.

${ }^{79}$ Rodríguez Medina, 'Anglicismos sintácticos en el sistema preposicional español: El caso de los manuales de informática traducidos', 404.

${ }^{80}$ Medina López, El anglicismo en el español actual, 75.

81 Pratt, El anglicismo en el español peninsular contemporáneo, 210.

82 Estrany Gendre, 'Calcos sintácticos del inglés', 202.

${ }_{83}$ Pratt, El anglicismo en el español peninsular contemporáneo, 211.

${ }^{84}$ Rodríguez Medina, 'Anglicismos sintácticos en el sistema preposicional español: El caso de los manuales de informática traducidos', 406.

${ }^{85}$ Lorenzo Criado, Anglicismos hispánicos, 619.

${ }^{86}$ For more on prepositional environments that are calqued from English source texts into Spanish target texts, vide Rodríguez Medina, 1998-1999.

${ }^{87}$ García González, 'Anglicismos morfosintácticos en la traducción periodística (inglés-español), 616.
} 
— The order inversion in negative tag-answers ('no' + noun/pronoun), as in the example

¿ ¿Puedo investigar?

- No Vd.

instead of "Vd. no" (Estrany Gendre, 1970; ${ }^{88}$ Pratt, 1980 ${ }^{89}$ ).

With regard to false Anglicisms, I will mainly follow Furiassi (2010) — quoted in Gottlieb and Furiassi $(2015)^{90}$ - since, as declared in section 2 (vide supra), his taxonomy seems to be the most comprehensive one of those established so far. However, I will adapt it to some extent. For the nomenclature employed to name some of the types he proposes, I will use the terminology suggested by other authors, as I attempt to select terms which are as descriptive, brief and accurate as possible. Moreover, I will add several categories to the ones established by Furiassi.

-Autonomous compounds (Furiassi, 2003) ${ }^{91}$ : two English free morphemes are joined to form a compound that does not exist in English, e.g. recordman (record + man) -Gottlieb and Furiassi, 2015- ${ }^{92}$

- English free morpheme + English suffix: the coinage of a new word based on an English free morpheme and an English suffix, e.g. footing ${ }^{93}$ (foot +- ing $)-$ Gottlieb and Furiassi, 2015-. ${ }^{94}$

— Spanish root / free morpheme + English suffix: An English ending (the '-ing' suffix is particulary productive in this case as well) is added to a Spanish base, e.g. puenting, tumbing, balconing.

—Truncated Anglicisms (Rodríguez González, 2003; ${ }^{95}$ Vélez Barreiro, 2003; ${ }^{96}$ Alejo González, 2002): the result of deleting one of the two elements (normally the head) of an English two-word compound, irrespective of the ellipsis rules of the English language, e.g. basket (from English basketball) —Gottlieb and Furiassi, 2015-.97 There are two subtypes within this kind of pseudo-Anglicism:

${ }^{88}$ Estrany Gendre, 'Calcos sintácticos del inglés', 203.

89 Pratt, El anglicismo en el español peninsular contemporáneo, 211.

${ }^{90}$ Gottlieb and Furiassi, 'Getting to Grips with False Loans and Pseudo-Anglicisms', 25-26.

${ }_{91}$ Furiassi, 'False Anglicisms in Italian Monolingual Dictionaries', 124.

92 Gottlieb and Furiassi, 'Getting to Grips with False Loans and Pseudo-Anglicisms', 25-26.

93 Sometimes, pseudo-Anglicisms do not fit perfectly into rigid categories (Furiassi, 2003, p.138). The word footing exemplifies this assertion, since it can be classified within two types of pseudo-Anglicism: "English free morpheme + English suffix" as well as "Assigning a new meaning to an English signifier".

94 Gottlieb and Furiassi, 'Getting to Grips with False Loans and Pseudo-Anglicisms', 25-26.

As Balteiro Fernández (2011, p.30) points out, “-ing forms (...) are apparently quite popular and frequent in Spanish”. For more on the '-ing' suffix, vide Navarro (2008, p.225), Balteiro Fernández (2014), and Mott (2015).

95 Rodríguez González, 'Orientaciones generales en torno a la elaboración de un corpus de anglicismos', 159.

96 Vélez Barreiro, 'Anglicismos en la prensa económica española', 43.

${ }^{97}$ Gottlieb and Furiassi, 'Getting to Grips with False Loans and Pseudo-Anglicisms', 25-26. 
(1) A word that formally looks like a non-adapted or an adapted overt lexical Anglicism. However, being used alone, it conveys a different meaning in Spanish and in English. For example, in the recipient tongue, "christmas" (DRAE, 23 $3^{\text {rd }}$ ed.: "1. m. tarjeta de Navidad") concentrates the sense of the original English compound "Christmas card", while in the original language "Christmas" does not refer to the same reality as "Christmas card" but to something else ("1. The annual Christian festival celebrating Christ's birth, held on 25 December in the Western Church. (...) 1.1. The period immediately before and after 25 December", Oxford Dictionary).

(2) A formally Spanish signifier that remains after the truncation of a lexical structural calque, as in "portátil", which has acquired the meaning of the whole term "ordenador portátil", an adapted lexical structural calque from English "portable computer" ("computer" > "ordenador", because French has acted as an intermediary language. In Latin-American Spanish, it is "computadora" the word that names the device, since the term has been adopted directly from US English without the influence of any other tongue).

-Clipping: the result obtained after clipping a genuine English word, e.g. happy end (from English happy ending) — Gottlieb and Furiassi, 2015-.98

- Spelling of the Spanish pronunciation of an English initialism: they consist of the writing of the Spanish pronunciation of English initialisms, e.g. cedé, elepé. The Diccionario Panhispánico de Dudas $(2005)^{99}$ by the RAE deals with this phenomenon in several entries. It declares that, sometimes, new words are created from foreign initialisms. But these new nouns should always represent the Spanish (rather than the original English) pronunciation of the abbreviation, as is claimed in the mentioned entries: "A partir de la lectura española de la sigla", "se desaconseja la forma (...), por corresponder a la lectura inglesa de la sigla".

- Assigning a new meaning to an English signifier: it consists of using an English word with a new sense that is not found in English, and can be illustrated by means of the lemma "book", which is employed in Spanish with the meaning 'album de fotos' but not with its original English sense 'libro'. Another example would be the term "auto-stop", which is employed in Spanish with the sense that French gave to it (DRAE, 23 $3^{\text {rd }}$ ed.: 100 " 1 . m. Forma de viajar por carretera solicitando transporte gratuito de los conductores de vehículos particulares"; in English, "hitch-hiking") rather than with its original English meaning, i.e. "A facility on a record player or (later more usually) a cassette player for automatically stopping operation once a record or cassette has played to the end, or when a cassette has finished rewinding or fast-forwarding" (Oxford Dictionary).

\footnotetext{
${ }^{98}$ Gottlieb and Furiassi, 'Getting to Grips with False Loans and Pseudo-Anglicisms', 25-26.

99 Real Academia Española, Diccionario panhispánico de dudas, 2005. www.rae.es

${ }^{100}$ Real Academia Española, Diccionario de la lengua española, 23 ${ }^{\mathrm{a}}$ ed., 2014, www.rae.es
} 
- Word-class change: When adopting the word, the recipient tongue considers it to belong to a different word class from the one it was originally classified into in the donor language (Gottlieb, 2015). ${ }^{101}$ The pair multitask (verb) $\rightarrow$ multitarea (noun) illustrates this phenomenon. ${ }^{102}$

- Misinterpretation: these cases occur when there is any kind of misunderstanding in relation to the English word on the part of the recipient language speakers, giving rise to the modification of this misinterpreted aspect. Examples of this issue are aeróbic ${ }^{103}$ and marshall. ${ }^{104}$

- Trademark turned into a common noun: A trademark which is not employed as a common noun in English has undergone this change of status in Spanish, thus being used in the recipient language as a generic name (for instance, $i \mathrm{Pad}$ ).

\section{CONCLUSIONS}

The present piece of research has provided an accurate definition of the concept of Anglicism as employed in the Spanish language nowadays. Moreover, a comprehensive typology of this linguistic phenomenon has been proposed, which means a step forward in relation to the existing ones due to the following two reasons: first, it encompasses both true and false Anglicisms, giving an overall picture of the issue; second, it adds two new categories in the area of pseudo-Anglicisms, namely "spelling of the Spanish pronunciation of an English initialism" and "misinterpretation". ${ }^{105}$

101 Gottlieb, 'Danish Pseudo-Anglicisms: A Corpus-Based Analysis', 64.

Knospe (2015, p. 114) refers to this phenomenon as "zero derivation or conversion".

${ }^{102}$ Note that there are cases in which the original English item can function as more than one word class. If, at least, one of them is maintained, the term will not be considered as a pseudo-Anglicism.

${ }^{103}$ Campos-Pardillos (2015) mentions the use of "aeróbic/aerobic" instead of importing the original English form "Aerobics" as an example of the category he calls morphological changes: "it appears that Spanish speakers have eliminated what they interpret as a plural form" (p.167) since non-native speakers usually make the mistake of considering the $-s$ in English nouns ending in -ics as a number morpheme.

${ }^{104}$ In this word, the last '- 1 ' should not be there. Probably the reason why it has been included is the fact that the "Marshall Plan" did contain two 'l' letters (since George Catlett's surname was spelt with a final double 'l'). Because the name of this Plan sounds familiar to Spanish people and, furthermore, it gave rise to the famous film Bienvenido Mr. Marshall (1953), the wrong spelling is thought to be correct.

105 Some cases comprised by this label are classified as "grafías hipercaracterizadas" by Pratt (1980, p.123), but, to my knowledge, they have not been included within a subtype of false Anglicisms before. 


\section{REFERENCES}

Alejo González, RAfael. 'Influencia del vocabulario económico inglés sobre los textos de economía españoles posteriores a la II Guerra Mundial'. Tesis Doctoral, Universidad Complutense de Madrid, 2002.

Alexieva, Nevena. 'Bulgarian'. In English in Europe, Manfred Görlach (ed.), 241-60. Oxford: Oxford University Press, 2002.

Araúz Gómez-Cadiñanos, Pedro. "El concepto de "anglicismo de frecuencia"”. In Actas de las II Jornadas de Lengua y Literatura Inglesa y Norteamericana, Logroño 7, 8 y 9 de febrero de 1990, Pedro Santana Martínez (ed. lit.), 7-16. Colegio Universitario de la Rioja, 1991. https://dialnet. unirioja.es/servlet/articulo?codigo $=555058$.

BALteiro Fernández, Isabel. 'A Reassessment of Traditional Lexicographical Tools in the Light of New Corpora: Sports Anglicisms in Spanish'. IJES, International Journal of English Studies 11, no. 2 (2011): 23-52.

— 'The Influence of English on Spanish Fashion Terminology: -ing Forms'. ESP Today. Journal of English for Specific Purposes at Tertiary Level 2, no. 2 (2014): 156-73.

Busse, Ulrich, And Manfred Görlach. 'German'. In English in Europe, Manfred Görlach (ed.)., 13-36. Oxford: Oxford University Press, 2002.

Campos-Pardillos, Miguel Ángel. 'All Is Not English That Glitters: False Anglicisms in the Spanish Language of Sports'. Atlantis. Journal of the Spanish Association for Anglo-American Studies 37, no. 2 (2015): 157-76.

Estrany Gendre, Manuel. 'Calcos sintácticos del inglés'. Filología Moderna 10, no. 38 (1970): 199-203.

Ferro, Ariadne M. 'An Analysis of Anglicisms in the Sports Sections of Granma and El Nuevo Herald'. In Linguistic Insights: Studies on Languages, Isabel de la Cruz Cabanillas \& Cristina Tejedor Martínez (eds.)., 121-29. Obras Colectivas UAH. Humanidades 37. Alcalá de Henares: Universidad de Alcalá. Servicio de Publicaciones, 2014.

Furiassi, Cristiano. False Anglicisms in Italian. Lexicography Worldwide. Polimetrica, 2010.

- 'False Anglicisms in Italian Monolingual Dictionaries: A Case Study of Some Electronic Editions'. International Journal of Lexicography. Oxford University Press 16, no. 2 (2003): 121-42. doi:10.1093/ij1/16.2.121.

García González, José EnRique. 'Anglicismos morfosintácticos en la traducción periodística (inglés-español): Análisis y clasificación'. CAUCE. Revista de Filología y Su Didáctica 20-21 (98 1997): 593-622.

Gómez Capuz, JuAn. 'Anglicismos en las noticias sobre la Guerra del Golfo Pérsico: Visión actual del problema e intento de clasificación'. LEA: Lingüística Española Actual 14, no. 2 (1992): 301-20.

- El préstamo lingüístico: Conceptos, problemas y métodos. Cuadernos de Filología, Anejo XXIX. Valencia: Universidad de Valencia, 1998.

— La inmigración léxica. Cuadernos de Lengua Española 84. Madrid: Arco/Libros, 2005.

- Préstamos del español: Lengua y sociedad. Cuadernos de Lengua Española 82. Madrid: Arco/ Libros, 2004.

- 'Towards a Typological Classification of Linguistic Borrowing (Illustrated with Anglicisms in Romance Languages)'. Revista Alicantina de Estudios Ingleses 10 (1997): 81-94.

GörLach, Manfred, ED. A Dictionary of European Anglicisms: A Usage Dictionary of Anglicisms in Sixteen European Languages. Oxford University Press, 2001.

Gottlieb, Henrik. 'Anglicisms and Translation'. In In and out of English: For Better, for Worse, Gunilla Anderman, Margaret Rogers (eds.), 161-184. Clevedon, GBR: Multilingual Matters Limited, 2005. 
— 'Danish Pseudo-Anglicisms: A Corpus-Based Analysis'. In Pseudo-English: Studies on False Anglicisms in Europe, Cristiano Furiassi and Henrik Gottlieb (eds.), 61-98. Language Contact and Bilingualism 9. Berlín / Boston / Munich: De Gruyter Mouton, 2015.

Gottlieb, Henrik, and Cristiano Furiassi. 'Getting to Grips with False Loans and Pseudo-Anglicisms'. In Pseudo-English: Studies on False Anglicisms in Europe, Cristiano Furiassi and Henrik Gottlieb (eds.), 9:3-33. Language Contact and Bilingualism. Berlín / Boston / Munich: De Gruyter Mouton, 2015.

Knospe, Sebastian. 'Pseudo-Anglicisms in the Language of the Contemporary German Press'. In Pseudo-English: Studies on False Anglicisms in Europe, Cristiano Furiassi and Henrik Gottlieb (eds.), 99-122. Language Contact and Bilingualism 9. Berlín / Boston / Munich: De Gruyter Mouton, 2015.

Lapesa Melgar, Rafael. 'Sobre transliteración de nombres propios extranjeros'. Boletin de La Real Academia Espanola 53 (1973): 279-87.

Lodares, Juan R. 'Penúltimos anglicismos semánticos en español'. Hispanic Journal 14, no. 1 (1993): $101-11$.

Lorenzo Criado, Emilio. Anglicismos hispánicos. Madrid: Gredos, 1996.

— 'La lengua española, hoy (VI). Anglicismos'. Boletín de La Fundación Juan March, November 1992.

Madariaga, Salvador De. ‘Vamos a Kahlahtahyood?' Revista de Occidente XII (March 1966): $365-73$.

Martínez de Sousa, José. 'Los anglicismos ortotipográficos en la traducción'.Panace@. 4, no. 11 (2003): $1-5$.

Maximova, Tamara. 'Russian'. In English in Europe, Manfred Görlach (ed.)., 195-212. Oxford: Oxford University Press, 2002.

Medina LóPez, JAVIer. El anglicismo en el español actual. 2a ed. Cuadernos de Lengua Española 51. Madrid: Arco/Libros, 2004.

Mott, Brian. 'The Rise of the English -ing Form in Modern Spanish: A Source of Pseudo-Anglicisms'. In Pseudo-English: Studies on False Anglicisms in Europe, Cristiano Furiassi and Henrik Gottlieb (eds.), 9:175-96. Language Contact and Bilingualism. Berlín / Boston / Munich: De Gruyter Mouton, 2015.

Navarro, Fernando A. 'La anglización del español: Mucho más allá de bypass, piercing, test, airbag, container y spa'. In Actas Del III Congreso «El Español, Lengua de Traducción» 12 a 14 de Julio, 2006. Puebla (México), 213-32. Bruselas: ESLEtRA, 2008.

OXFORD DICTIONARIES, HTTPS://www.oxforddictionaries.com/

Pratt, Chris. El anglicismo en el español peninsular contemporáneo. Madrid: Gredos, 1980.

Pulcini, Virginia. 'Italian'. In English in Europe, Manfred Görlach (ed.)., 151-67. Oxford: Oxford University Press, 2002.

Pulcini, Virginia, Cristiano Furiassi, and Félix Rodríguez González. 'The Lexical Influence of English on European Languages. From Words to Phraseology'. In The Anglicization of European Lexis, 1-24. Amsterdam / Philadelphia: John Benjamins Publishing Company, 2012.

Real Academia Española, Diccionario panhispánico de DUdas, 2005, Www.rae.es

Real Academia Española, Diccionario de la lengua española, 20I4, www.rae.es

Real Academia Española, Ortografía de la lengua española, 20io, pp.542-543 [Online edition (www.rae.es).

Rodríguez Díaz, José Antonio. 'Anglicismos y germanismos en el lenguaje de la publicidad del español peninsular contemporáneo 1998-2007'. Tesis Doctoral, Universidad de Santiago de Compostela, 2011. https://www.educacion.es/teseo/mostrarRef.do?ref=940800.

Rodríguez GonZÁlez, FÉLIX. 'Orientaciones generales en torno a la elaboración de un corpus de an- 
glicismos'. In Lexicografía y Lexicogía En Europa y América: Homenaje a Günter Haensch, M.T. Echenique Elizondo \& J. Sánchez Méndez (eds.), 559-575. Madrid: Gredos, 2003. http://dialnet. unirioja.es/servlet/articulo?codigo $=759699$.

— 'Spanish'. In English in Europe, Manfred Görlach (ed.), 128-150 (ch.7). Oxford: Oxford University Press, 2002.

Rodríguez Medina, M Mesús. 'Los anglicismos de frecuencia sintácticos en los manuales de informática traducidos'. Tesis Doctoral, Universidad de Las Palmas de Gran Canaria, 2000. https:// www.educacion.es/teseo/mostrarRef.do?ref=237909.

- 'Anglicismos sintácticos en el sistema preposicional español: El caso de los manuales de informática traducidos'. Revista de Lenguas Para Fines Específicos 5 y 6 (1999 1998): 394-413.

- 'Los anglicismos de frecuencia sintácticos en español: Estudio empírico'. Revista Española de Lingüística Aplicada, no. 15 (2002): 149-70.

Rodríguez Segura, Delia. 'Pasado y presente del anglicismo. Análisis de un corpus de anglicismos actuales en distintos medios de comunicación españoles.' Tesis Doctoral, Universidad de Almería, 1998. https://www.educacion.es/teseo/mostrarRef.do?ref=223134.

Stathi, Ekaterini. 'Modern Greek', Manfred Görlach (ed.), 301-30. Oxford: Oxford University Press, 2002.

VÁzQuez-Ayora, Gerardo. Introducción a La Traductología: Curso básico de traducción. Georgetown: Georgetown University Press, 1977.

Vélez Barreiro, Marco. 'Anglicismos en la prensa económica española'. Tesis Doctoral, Universidade A Coruña, 2003.

https://www.educacion.es/teseo/mostrarRef.do?ref=297750. 